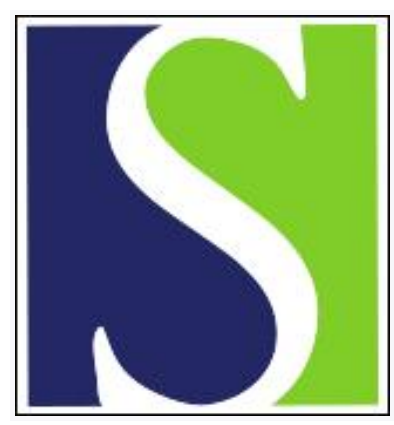

Scand J Work Environ Health 2001;27(2):113-119

https://doi.org/10.5271/sjweh.597

Issue date: Apr 2001

Cohort cancer incidence among pulp and paper mill workers in British Columbia

by Band PR, Le ND, Fang R, Astrakianakis G, Bert J, Keefe A, Krewski D

Affiliation: Health Canada, 1001 St-Laurent, Longueuil, Québec, Canada, J4K 1C7. pierre_band@hc-sc.gc.ca

Refers to the following text of the Journal: 1997;23(6):458-461

The following article refers to this text: 2002;28(5):333-340

Key terms: British Columbia; cancer incidence; kraft; leukemias; prostate cancer; pulp and paper mill; rectal cancer; stomach cancer; sulfite; worker

This article in PubMed: www.ncbi.nlm.nih.gov/pubmed/11409593 


\title{
Cohort cancer incidence among pulp and paper mill workers in British Columbia
}

\author{
by Pierre R Band, MD, ${ }^{1,2,5}$ Nhu D Le, PhD, ${ }^{1}$ Raymond Fang, MSc, ${ }^{1}$ George Astrakianakis, MEng, ${ }^{1}$ \\ Joel Bert, PhD, ${ }^{3}$ Anya Keefe, MSc, ${ }^{1,4}$ Daniel Krewski, PhD ${ }^{2,5}$
}

Band PR, Le ND, Fang R, Astrakianakis G, Bert J, Keefe A, Krewski D. Cohort cancer incidence among pulp and paper mill workers in British Columbia. Scand J Work Environ Health 2001;27(2):113—119.

\begin{abstract}
Objectives A study was conducted to investigate cancer risks in a cohort of pulp and paper workers.
Methods All male workers with $\geq 1$ years of employment in 14 pulp and paper mills in 1950-1992 were studied. Standardized incidence ratios (SIR) were used to compare the cancer incidence of the cohort with that of the Canadian male population. Record linkage with the National Cancer Registry was performed using the generalized iterative record linkage method.

Results Altogether 1756 cancer cases were observed in the entire cohort. For $\geq 15$ years of work, the entire cohort had significantly increased SIR values for pleural and prostate cancer and skin melanoma; there was also a significantly increased risk for skin melanoma among workers in the kraft process only, rectal cancer among workers in the sulfite process only, and stomach and prostate cancer and all leukemias combined among workers in both the kraft and sulfite processes. A separate analysis comparing workers in pulping and papermaking with those in the pulping process only did not reveal any difference in cancer risk and hence did not modify the results. The SIR values for skin melanoma were not significantly increased in a comparison using the British Columbia male population. Nine of 10 pleural cancers were mesotheliomas, which likely reflect past asbestos exposure.

Conclusions The results suggest that long-term work in the pulp and paper industry is associated with excess risks of prostate and stomach cancers and all leukemias for work in both kraft and sulfite processes and of rectal cancer for work in the sulfite process only.
\end{abstract}

Key terms kraft, leukemias, prostate cancer, rectal cancer, stomach cancer, sulfite.

Pulp and paper is a major industry in Canada and a primary one in British Columbia, the most westerly Canadian province. Wood can be converted to pulp by several processes, the most prevalent in Canada being chemical. In chemical pulping, lignin is solubilized under the following 2 conditions: alkaline, also called the kraft or sulfate process, and acidic or sulfite process, the former being the most common. During chemical pulping, exposures to known or suspected carcinogens can occur, including exposure to organic chlorinated compounds, sulfuric acid mist, formaldehyde, and arsenic and chloroform, the last two having been previ- ously used as antisap stain and involving a small level of exposure. In a previous publication, we reported the cancer mortality experience of the chemical pulping process by type for a cohort of 30157 pulp and paper workers in British Columbia (1). Cancer risks significantly associated with work duration and time from first employment of $\geq 15$ years were observed for cancer of the pleura, kidney and brain in the total cohort, for kidney cancer among the kraft mill workers only, for Hodgkin's disease among the sulfite mill workers only, and for esophageal cancer among the workers ever employed in both kraft and sulfite mills. Epidemiologic

1 Cancer Control Research, BC Cancer Agency, Vancouver, British Columbia, Canada.

2 Health Protection Branch, Health Canada, Ottawa, Ontario, Canada.

3 Department of Chemical Engineering, University of British Columbia, Vancouver, Canada.

4 School of Occupational and Environmental Hygiene, University of British Columbia, Vancouver, Canada.

5 Department of Epidemiology and Community Medicine, University of Ottawa, Ottawa, Canada.

Reprint requests to: Dr Pierre R Band, Health Canada, 1001 St-Laurent, Longueuil, Québec, Canada, J4K 1 C7. [E-mail: pierre_band@hc-sc.gc.ca] 
Table 1. Cohort characteristics of the cohort cancer incidence study of pulp and paper mill workers, British Columbia, Canada, $1969-1992$.

\begin{tabular}{|c|c|c|c|c|c|c|c|c|c|c|c|}
\hline \multirow{3}{*}{ Process } & & & & & \multicolumn{3}{|c|}{ Age at end of study (years) } & \multicolumn{3}{|c|}{ Years worked } & \multirow{3}{*}{$\begin{array}{l}\text { Worked in } \\
\text { one mill } \\
(\%)\end{array}$} \\
\hline & \multicolumn{2}{|c|}{ Workers } & \multicolumn{2}{|c|}{ Person-years } & & & & & & & \\
\hline & N & $\%$ & N & $\%$ & Mean & SD & Median & Mean & SD & Median & \\
\hline Kraft only & 20041 & 70.9 & 323476 & 68 & 47.0 & 12.7 & 46 & 11.1 & 9.1 & 8 & 96.0 \\
\hline $\begin{array}{l}\text { Sulfite only } \\
\text { Kraft and sulfite }\end{array}$ & $\begin{array}{l}3756 \\
4481\end{array}$ & $\begin{array}{l}13.3 \\
15.8\end{array}$ & $\begin{array}{l}63971 \\
88340\end{array}$ & $\begin{array}{l}13 \\
19\end{array}$ & $\begin{array}{l}57.2 \\
55.1\end{array}$ & $\begin{array}{l}15.8 \\
13.2\end{array}$ & $\begin{array}{l}58 \\
53\end{array}$ & $\begin{array}{r}8.2 \\
16.9\end{array}$ & $\begin{array}{r}8.8 \\
13.2\end{array}$ & $\begin{array}{r}5 \\
15\end{array}$ & $\begin{array}{l}98.2 \\
81.0\end{array}$ \\
\hline All & 28278 & & 475787 & & 49.6 & 13.9 & 48 & 11.6 & 10.1 & 8 & 93.9 \\
\hline
\end{tabular}

studies specifically designed to investigate pulp and paper workers have mainly been mortality studies (2-14), with only 3 reporting cancer incidence results (15-17). This report presents the cancer incidence outcomes of 28278 members of the British Columbia pulp and paper cohort.

\section{Subjects and methods}

Details of the methods have been described previously (1). Before the study was initiated, a feasibility study was conducted with the following eligibility criteria for pulp and paper mill inclusion: (i) start of production in 1970 or earlier, (ii) minimum of 1000 workers ever employed by the mill, and (iii) availability of records for all employees. Of the 21 mills in British Columbia, 14 met these criteria and were included in the study. The main industrial process of these 14 mills was pulping, whereas 7 also included papermaking. All male workers with at least 1 year of employment in these 14 mills as of or since 1 January 1950 until 31 December 1992, the cutoff date for follow-up, were enrolled in the cohort. The data collection included full name and dates of birth, hire, and termination of employment. Information on tobacco smoking and other cancer risk factors related to life-style was not available.

The mortality cohort consisted of a total of 30157 workers (1). Of these, 1889 (6.3\%) were excluded from the cancer incidence cohort due to the following events, which occurred prior to 1969: 1134 were lost to followup, 552 died from noncancer causes, 175 had been diagnosed with cancer. Previously missing birthdate information from the mortality cohort was found for 10 workers, who were added to the incidence cohort. Thus altogether 28278 workers were included in the analysis. The characteristics of the cohort are shown in table 1. Of the 28278 workers, 20041 (70.9\%) worked in the kraft process only, 3756 (13.3\%) were employed in the sulfite process only, and 4481 (15.8\%) had worked in both processes. All of the workers were exposed to the pulping process. The number of workers also exposed to the paper-making process in the total cohort and in the 3 subcohorts was (i) $16080(56.9 \%)$ of all the workers, (ii) $12647(63.2 \%)$ of the workers employed in the kraft process only, $942(25.1 \%)$ of the workers employed in the sulfite process only, and 2491 (55.6\%) of the workers employed in both the kraft and sulfite processes. Over $95 \%$ of those in all the processes were successfully traced.

\section{Statistical procedure}

Standardized incidence ratios (SIR) were used to compare the cancer incidence of the cohort with that of the Canadian male population. The Canadian population incidence rates, obtained from the Laboratory Centre for Disease Control, Health Canada, were calculated by 5year age groups and 5-year calendar periods dating back to 1 January 1969 . Person-years at risk were calculated from 1 year after the date of hire to 31 December 1992 or to the year of death or of cancer incidence, whichever came first. For workers lost to follow-up, observations were censored at the date when last known to be alive. Latency effects were examined using work duration and time since first employment calculated from 1 year after the date of hire. Time since first employment was calculated to the last follow-up date. A 15-year latency cutoff was selected because the person-year distribution of all the workers with time from first exposure of $\geq 15$ years ( 210546 person-years) was equally distributed between those with $<15$ years of employment (110 211 or $52.4 \%$ ) and those with $\geq 15$ of employment (100 335 or 47.6\%). Similarly, the total number of cancer cases in these 2 subgroups was almost equal (685 versus 724). Tests of significance and the SIR values were calculated on the assumption that the observed number of events followed a Poisson distribution with the mean given by the expected number of events (18); $90 \%$ confidence intervals $(90 \% \mathrm{CI})$ corresponding to a one-sided 5\% significance test were used. Record linkage of the cohort with the National Cancer Registry was performed at Statistics Canada using the generalized iterative record linkage method $(19,20)$. In Canada, 
Cancer status

\begin{tabular}{|c|c|c|c|c|c|c|c|c|c|c|c|c|c|c|c|}
\hline \multicolumn{6}{|c|}{ No cancer } & \multicolumn{6}{|c|}{ Cancer } & \multicolumn{4}{|c|}{ Total } \\
\hline \multicolumn{2}{|c|}{ Active } & \multicolumn{2}{|c|}{ Terminated } & \multicolumn{2}{|c|}{ Total } & \multicolumn{2}{|c|}{ Alive } & \multicolumn{2}{|c|}{ Dead } & \multicolumn{2}{|c|}{ Total } & \multicolumn{2}{|c|}{ Unknown } & \multicolumn{2}{|c|}{ Traced } \\
\hline N & $\%$ & N & $\%$ & $N$ & $\%$ & N & $\%$ & N & $\%$ & $N$ & $\%$ & N & $\%$ & $\mathrm{~N}$ & $\%$ \\
\hline 8927 & 47.8 & 9768 & 52.2 & 18695 & 93.3 & 303 & 35.6 & 547 & 64.4 & 850 & 4.2 & 496 & 2.5 & 19545 & 97.5 \\
\hline $\begin{array}{l}420 \\
942\end{array}$ & $\begin{array}{l}13.1 \\
24.4\end{array}$ & $\begin{array}{l}2775 \\
2915\end{array}$ & $\begin{array}{l}86.9 \\
75.6\end{array}$ & $\begin{array}{l}3195 \\
3857\end{array}$ & $\begin{array}{l}85.0 \\
96.0\end{array}$ & $\begin{array}{l}114 \\
115\end{array}$ & $\begin{array}{l}24.6 \\
26.0\end{array}$ & $\begin{array}{l}350 \\
327\end{array}$ & $\begin{array}{l}75.4 \\
74.0\end{array}$ & $\begin{array}{l}464 \\
442\end{array}$ & $\begin{array}{r}12.4 \\
9.9\end{array}$ & $\begin{array}{r}97 \\
182\end{array}$ & $\begin{array}{l}2.6 \\
4.1\end{array}$ & $\begin{array}{l}3659 \\
4299\end{array}$ & $\begin{array}{l}97.4 \\
95.9\end{array}$ \\
\hline 10289 & 40.0 & 15458 & 60.0 & 25747 & 91.1 & 532 & 30.3 & 1224 & 69.7 & 1756 & 6.2 & 775 & 2.7 & 27503 & 97.3 \\
\hline
\end{tabular}

ascertainment of cancer incidence cases on a national basis dates back to 1969 (21), hence the 1 January 1969 follow-up starting date of this study. Cancer diagnoses were coded according to the 9th revision of the International Classification of Diseases (22).

\section{Results}

\section{Incidence and latency analyses}

Results of the cancer incidence analyses for the total cohort and the chemical processes are shown in table 2

Table 2. Standardized incidence ratios (SIR) for all cancers and cancer sites with $\geq 4$ cases for each mill process and for all workers in the cohort incidence study of pulp and paper mill workers, British Columbia, Canada, 1969-1992. $(0=$ observed number of cases, $90 \% \mathrm{Cl}=90 \%$ confidence interval)

\begin{tabular}{|c|c|c|c|c|c|c|c|c|c|c|c|c|}
\hline \multirow[b]{2}{*}{ Cancer site ${ }^{a}$} & \multicolumn{3}{|c|}{ Kraft only } & \multicolumn{3}{|c|}{ Sulfite only } & \multicolumn{3}{|c|}{ Both sulfite \& kraft } & \multicolumn{3}{|c|}{ All workers } \\
\hline & 0 & SIR & $90 \% \mathrm{Cl}$ & 0 & $\operatorname{SIR}$ & $90 \% \mathrm{Cl}$ & 0 & $\operatorname{SIR}$ & $90 \% \mathrm{Cl}$ & 0 & SIR & $90 \% \mathrm{Cl}$ \\
\hline All Cancer (140-172,174-208) & 850 & 0.91 & $0.86-0.96$ & 464 & 1.17 & $1.08-1.26$ & 442 & 1.05 & $0.97-1.13$ & 1756 & 1.00 & $0.96-1.04$ \\
\hline $\begin{array}{l}\text { Tongue, mouth \& pharynx } \\
(141,143-149)\end{array}$ & 25 & 0.75 & $0.52-1.05$ & 11 & 0.91 & $0.51-1.50$ & 12 & 0.92 & $0.53-1.49$ & 48 & 0.82 & $0.64-1.04$ \\
\hline Esophagus (150) & 8 & 0.64 & $0.32-1.16$ & 7 & 1.26 & $0.59-2.37$ & 5 & 0.87 & $0.34-1.83$ & 20 & 0.84 & $0.56-1.23$ \\
\hline Stomach (151) & 34 & 0.95 & $0.70-1.27$ & 17 & 0.94 & $0.60-1.41$ & 27 & 1.52 & $1.07-2.09$ & 78 & 1.09 & $0.89-1.31$ \\
\hline Colon (153) & 68 & 0.90 & $0.73-1.10$ & 34 & 0.98 & $0.72-1.30$ & 30 & 0.83 & $0.60-1.13$ & 132 & 0.90 & $0.78-1.04$ \\
\hline Rectum (154) & 30 & 0.61 & $0.44-0.82$ & 27 & 1.24 & $0.88-1.72$ & 24 & 1.06 & $0.73-1.49$ & 81 & 0.86 & $0.71-1.04$ \\
\hline Liver $(1550,1551)$ & 8 & 1.05 & $0.52-1.90$ & 8 & 2.77 & $1.38-5.00$ & 2 & .. & .. & 18 & 1.32 & $0.85-1.95$ \\
\hline Gallbladder (156) & 2 & .. & .. & 2 & .. & .. & 4 & 1.57 & $0.53-3.58$ & 8 & 0.78 & $0.39-1.40$ \\
\hline Pancreas (157) & 16 & 0.64 & $0.40-0.97$ & 21 & 1.77 & $1.19-2.55$ & 12 & 0.99 & $0.57-1.60$ & 49 & 1.00 & $0.78-1.27$ \\
\hline Larynx (161) & 13 & 0.57 & $0.33-0.90$ & 12 & 1.33 & $0.77-2.16$ & 7 & 0.72 & $0.34-1.35$ & 32 & 0.77 & $0.56-1.03$ \\
\hline Lung (1622-1625,1628-1629) & 164 & 0.84 & $0.73-0.95$ & 112 & 1.32 & $1.12-1.55$ & 80 & 0.87 & $0.71-1.05$ & 356 & 0.95 & $0.87-1.04$ \\
\hline Pleura (163) & 5 & 1.78 & $0.70-3.74$ & 3 & .. & .. & 2 & .. & .. & 10 & 2.05 & $1.11-3.47$ \\
\hline Bone (170) & 3 & .. & .. & - & .. & .. & 1 & .. & .. & 4 & 0.69 & $0.23-1.57$ \\
\hline Connective tissue $(1641,171)$ & 7 & 0.86 & $0.40-1.61$ & 4 & 1.61 & $0.55-3.68$ & 2 & .. & .. & 13 & 0.96 & $0.57-1.52$ \\
\hline Skin melanoma (172) & 45 & 1.55 & $1.19-1.99$ & 10 & 1.39 & $0.75-2.35$ & 17 & 1.87 & $1.19-2.81$ & 72 & 1.59 & $1.29-1.93$ \\
\hline Prostate (185) & 167 & 1.36 & $1.19-1.55$ & 78 & 1.11 & $0.92-1.34$ & 100 & 1.46 & $1.23-1.73$ & 345 & 1.32 & $1.21-1.44$ \\
\hline Testis (186) & 16 & 0.92 & $0.58-1.39$ & 3 & .. & & 4 & 1.03 & $0.35-2.36$ & 23 & 0.96 & $0.66-1.36$ \\
\hline Kidney $(1890,1,2)$ & 26 & 0.84 & $0.59-1.16$ & 12 & 1.06 & $0.61-1.72$ & 15 & 1.18 & $0.73-1.82$ & 53 & 0.96 & $0.76-1.21$ \\
\hline Bladder (188) & 41 & 0.73 & $0.55-0.95$ & 23 & 0.87 & $0.59-1.23$ & 15 & 0.55 & $0.34-0.85$ & 79 & 0.72 & $0.59-0.87$ \\
\hline Eye (190) & 6 & 2.12 & $0.92-4.18$ & 1 &.. & .. & 1 & .. & .. & 8 & 1.61 & $0.80-2.91$ \\
\hline Brain (191) & 23 & 0.99 & $0.68-1.41$ & 10 & 1.53 & $0.83-2.59$ & 10 & 1.24 & $0.67-2.10$ & 43 & 1.14 & $0.87-1.47$ \\
\hline Thyroid (193) & 8 & 1.06 & $0.53-1.92$ & 3 & .. & .. & 3 & .. & .. & 14 & 1.21 & $0.73-1.89$ \\
\hline Hodgkin's disease (201) & 10 & 0.75 & $0.41-1.28$ & 2 & .. & .. & 4 & 1.07 & $0.36-2.45$ & 16 & 0.81 & $0.51-1.23$ \\
\hline Non-Hodgkin's lymphoma $(200,202)$ & 45 & 1.07 & $0.82-1.37$ & 12 & 0.91 & $0.53-1.47$ & 17 & 1.10 & $0.70-1.64$ & 74 & 1.05 & $0.86-1.27$ \\
\hline Multiple myeloma (203) & 6 & 0.56 & $0.24-1.09$ & 5 & 1.03 & $0.40-2.16$ & 4 & 0.78 & $0.26-1.78$ & 15 & 0.72 & $0.44-1.11$ \\
\hline Lymphocytic leukemia (204) & 10 & 0.83 & $0.45-1.41$ & 7 & 1.34 & $0.63-2.51$ & 7 & 1.28 & $0.60-2.40$ & 24 & 1.06 & $0.73-1.49$ \\
\hline Myeloid leukemia (205) & 11 & 0.90 & $0.50-1.48$ & 4 & 0.97 & $0.33-2.21$ & 7 & 1.48 & $0.69-2.78$ & 22 & 1.04 & $0.70-1.48$ \\
\hline Leukemia (204-208) & 26 & 0.92 & $0.64-1.27$ & 14 & 1.24 & $0.75-1.93$ & 18 & 1.48 & $0.96-2.19$ & 58 & 1.12 & $0.89-1.39$ \\
\hline
\end{tabular}

\footnotetext{
a Code of the International Classification of Diseases, ninth revision, in parentheses.
} 
for any cancer site with a minimum of 4 cases per site. Latency analyses are reported in tables 3-6 for work duration and time since first employment of $<15$ years and $\geq 15$ years; in these tables, data are shown for any cancer site with statistically significant increased or decreased SIR values or a nonsignificant excess risk of $50 \%$ or greater observed for a work duration of $\geq 15$ years.

\section{Total cohort}

A total of 1756 cancer cases was observed (table 1). The SIR values were increased for skin melanoma and pleural, prostate, and eye cancer (table 2) and decreased for bladder cancer. The SIR values for a work duration of $\geq 15$ years (table 3 ) were significantly increased for skin melanoma and pleural and prostate cancer; the relative risks were significantly decreased for all cancers and for cancer of the tongue, mouth, pharynx, colon, lung, and bladder.

\section{Workers employed only in the kraft process}

A total of 850 cancer cases was observed (table 1) for the workers employed only in the kraft process. The SIR

Table 3. Latency analysis for all the workers. $(0=0 b s e r v e d$ number of cases, $\mathrm{SIR}=$ standardized incidence ratio, $90 \% \mathrm{CI}=$ $90 \%$ confidence interval)

\begin{tabular}{|c|c|c|c|c|c|c|}
\hline \multirow[b]{3}{*}{ Cancer site ${ }^{\mathrm{a}}$} & \multicolumn{6}{|c|}{ Work duration } \\
\hline & \multicolumn{3}{|c|}{$<15$ years } & \multicolumn{3}{|c|}{$\geq 15$ years } \\
\hline & 0 & SIR & $90 \% \mathrm{Cl}$ & 0 & SIR & $90 \% \mathrm{Cl}$ \\
\hline \multicolumn{7}{|l|}{$\begin{array}{l}\text { All cancer } \\
(140-172,174-208)\end{array}$} \\
\hline$<15$ years' employment & 347 & 0.98 & $0.89-1.07$ & - & .. & .. \\
\hline$\geq 15$ years' employment & 685 & 1.13 & $1.06-1.21$ & 724 & 0.91 & $0.86-0.97$ \\
\hline \multicolumn{7}{|l|}{$\begin{array}{l}\text { Tongue, mouth, \& pharynx } \\
(141,143-149)\end{array}$} \\
\hline$<15$ years' employment & 10 & 0.72 & $0.39-1.22$ & - & $\cdot \cdot$ &.$\cdot$ \\
\hline$\geq 15$ years' employment & 28 & 1.37 & $0.97-1.88$ & 10 & 0.41 & $0.22-0.70$ \\
\hline \multicolumn{7}{|l|}{ Lung (162.2-5, 162.8-9) } \\
\hline$<15$ years' employment & 49 & 0.76 & $0.59-0.96$ & - & $\cdot \cdot$ &.$\cdot$ \\
\hline$\geq 15$ years' employment & 173 & 1.31 & $1.15-1.49$ & 134 & 0.76 & $0.65-0.88$ \\
\hline \multicolumn{7}{|l|}{ Pleura (163) } \\
\hline$<15$ years' employment & 3 & 3.34 & $0.90-8.61$ & - & .. & .. \\
\hline$\geq 15$ years' employment & 1 & 0.54 & $0.02-2.57$ & 6 & 2.80 & $1.22-5.52$ \\
\hline \multicolumn{7}{|l|}{ Skin melanoma (172) } \\
\hline$<15$ years' employment & 20 & 1.25 & $0.83-1.82$ & - & $\cdot \cdot$ & .. \\
\hline$\geq 15$ years' employment & 26 & 1.76 & $1.23-2.44$ & 26 & 1.78 & $1.25-2.48$ \\
\hline \multicolumn{7}{|l|}{ Prostate (185) } \\
\hline$<15$ years' employment & 35 & 1.61 & $1.19-2.13$ & - & $\cdot$. &.$\cdot$ \\
\hline$\geq 15$ years' employment & 135 & 1.38 & $1.19-1.59$ & 175 & 1.24 & $1.09-1.40$ \\
\hline \multicolumn{7}{|l|}{ Bladder (188) } \\
\hline$<15$ years' employment & 19 & 0.94 & $0.62-1.38$ & - & .. &.$\cdot$ \\
\hline$\geq 15$ years' employment & 27 & 0.71 & $0.50-0.98$ & 33 & 0.64 & $0.47-0.85$ \\
\hline \multicolumn{7}{|l|}{ Colon (153) } \\
\hline$<15$ years' employment & 30 & 1.16 & $0.84-1.57$ & - & .. &.$\cdot$ \\
\hline$\geq 15$ years' employment & 50 & 0.97 & $0.76-1.23$ & 52 & 0.75 & $0.59-0.95$ \\
\hline
\end{tabular}

a Code of the International Classification of Diseases, ninth revision, in parentheses. values for skin melanoma and prostate, pleural, and eye cancer were elevated (table 2); the SIR values were decreased for all cancers and for cancer of the pancreas, larynx, lung, and bladder. For a work duration of $\geq 15$ years (table 4), the relative risks were significantly increased for malignant melanoma and significantly decreased for all cancers and cancer of the tongue, mouth, pharynx, rectum, lung, and bladder.

Table 4. Latency analysis for workers employed in the kraft process only. ( $0=$ observed number of cases, $\mathrm{SIR}=$ standardized incidence ratio, $90 \% \mathrm{Cl}=90 \%$ confidence interval)

\begin{tabular}{|c|c|c|c|c|c|c|}
\hline \multirow[b]{3}{*}{ Cancer site ${ }^{a}$} & \multicolumn{6}{|c|}{ Work duration } \\
\hline & \multicolumn{3}{|c|}{$<15$ years } & \multicolumn{3}{|c|}{$\geq 15$ years } \\
\hline & 0 & SIR & $90 \% \mathrm{Cl}$ & 0 & SIR & $90 \% \mathrm{Cl}$ \\
\hline \multicolumn{7}{|l|}{$\begin{array}{l}\text { All cancer } \\
(140-172,174-208)\end{array}$} \\
\hline$<15$ years' employment & 271 & 0.95 & $0.86-1.05$ & - &.$\cdot$ &.$\cdot$ \\
\hline$\geq 15$ years' employment & 277 & 1.03 & $0.93-1.14$ & 302 & 0.80 & $0.72-0.88$ \\
\hline \multicolumn{7}{|l|}{$\begin{array}{l}\text { Tongue, mouth \& pharynx } \\
(141,143 \text { - 149) }\end{array}$} \\
\hline$<15$ years' employment & 7 & 0.62 & $0.29-1.17$ & - & .. & .. \\
\hline$\geq 15$ years' employment & 14 & 1.53 & $0.93-2.40$ & 4 & 0.31 & $0.11-0.71$ \\
\hline \multicolumn{7}{|l|}{ Rectum (154) } \\
\hline$<15$ years' employment & 9 & 0.64 & $0.33-1.12$ & - & .. & .. \\
\hline$\geq 15$ years' employment & 8 & 0.55 & $0.27-0.99$ & 13 & 0.62 & $0.37-0.99$ \\
\hline \multicolumn{7}{|l|}{ Lung (162.2-5, 162.8-9) } \\
\hline$<15$ years' employment & 41 & 0.78 & $0.59-1.02$ & - & .. & .. \\
\hline$\geq 15$ years' employment & 69 & 1.20 & $0.97-1.46$ & 54 & 0.63 & $0.49-0.79$ \\
\hline \multicolumn{7}{|l|}{ Skin melanoma (172) } \\
\hline$<15$ years' employment & 13 & 1.01 & $0.60-1.60$ & - & .. & .. \\
\hline$\geq 15$ years' employment & 17 & 2.29 & $1.46-3.43$ & 15 & 1.73 & $1.06-2.66$ \\
\hline \multicolumn{7}{|l|}{ Bladder (188) } \\
\hline$<15$ years' employment & 14 & 0.87 & $0.52-1.35$ & - & .. & .. \\
\hline$\geq 15$ years' employment & 15 & 0.90 & $0.56-1.39$ & 12 & 0.51 & $0.29-0.83$ \\
\hline
\end{tabular}

${ }^{a}$ Code of the International Classification of Diseases, ninth revision, in parentheses.

Table 5. Latency analysis for workers employed in the sulfite process only. ( $0=$ observed number of cases, SIR = standardized incidence ratio, $95 \% \mathrm{Cl}=90 \%$ confidence interval)

\begin{tabular}{|c|c|c|c|c|c|c|}
\hline \multirow[b]{3}{*}{ Cancer site $^{a}$} & \multicolumn{6}{|c|}{ Work duration } \\
\hline & \multicolumn{3}{|c|}{$<15$ years } & \multicolumn{3}{|c|}{$\geq 15$ years } \\
\hline & 0 & SIR & $90 \% \mathrm{Cl}$ & 0 & SIR & $90 \% \mathrm{Cl}$ \\
\hline \multicolumn{7}{|l|}{ Rectum (154) } \\
\hline$<15$ years' employment & 1 & 0.72 & $0.03-3.42$ & - & .. & .. \\
\hline${ }^{315}$ years' employment & 15 & 1.03 & $0.64-1.59$ & 11 & 1.90 & $1.07-3.15$ \\
\hline \multicolumn{7}{|l|}{ Skin melanoma (172) } \\
\hline$<15$ years' employment & 1 & 0.88 & $0.03-4.17$ & - &.. & .. \\
\hline$\geq 15$ years' employment & 6 & 1.21 & $0.53-2.39$ & 3 & 2.65 & $0.72-6.85$ \\
\hline
\end{tabular}

${ }^{a}$ Code of the International Classification of Diseases, ninth revision, in parentheses. 


\section{Workers employed only in the sulfite process}

A total of 464 cancer cases was observed for the workers employed only in the sulfite process (table 1). The SIR values for all cancers and cancer of the liver, pancreas, lung, connective tissue, and brain were increased. For a work duration of $\geq 15$ years (table 5 ), the SIR values were increased for skin melanoma and cancer of the rectum.

\section{Workers employed in both the kraft and the sulfite processes}

A total of 442 cancer cases was observed for the workers employed in both the kraft and the sulfite processes (table 1). The SIR values were increased for skin melanoma and cancer of the stomach, gallbladder, and prostate and decreased for bladder cancer. For a work duration of $\geq 15$ years (table 6 ), the relative risks were increased for skin melanoma and cancer of the stomach, gallbladder, and prostate, and also for myeloid leukemias and all leukemias. The relative risk was low for bladder cancer.

\section{Comparison of workers exposed to the pulping and paper-making process with those exposed to the pulping process only}

We analyzed the data comparing workers exposed only to the pulping process with those exposed to the pulping and papermaking processes. These comparative analyses were carried out for all workers and also for each of the three subcohorts. The results (data not shown) were similar to those already described for the pulping and papermaking processes together, and they did not reveal significant differences in the cancer risks for workers exposed to the paper-making process in addition to the pulping process.

\section{Discussion}

An increased incidence for several cancer sites was observed in the cohort of pulp and paper workers described in this study. Significantly elevated SIR values in association with a work duration of $\geq 15$ years, hereafter referred to as long-term work, were noted for cancers of the stomach, rectum, pleura and prostate, for skin melanoma, and for all leukemias. The numbers were too few to assess meaningfully the elevated risk observed for eye cancer among the long-term workers in the total cohort. The relative risk for stomach cancer was significantly increased among the long-term workers exposed to both the kraft and sulfite processes. A risk of stomach cancer has been reported in mortality, case-
Table 6. Latency analysis for the workers ever employed in both the kraft and sulfite processes. ( $0=$ observed number of cases, $\mathrm{SIR}=$ standardized incidence ratio, $90 \% \mathrm{Cl}=90 \%$ confidence interval)

\begin{tabular}{|c|c|c|c|c|c|c|}
\hline \multirow[b]{3}{*}{ Cancer site $^{\mathrm{a}}$} & \multicolumn{6}{|c|}{ Work duration } \\
\hline & \multicolumn{3}{|c|}{$<15$ years } & \multicolumn{3}{|c|}{$\geq 15$ years } \\
\hline & 0 & SIR & $90 \% \mathrm{Cl}$ & 0 & SIR & $90 \% \mathrm{Cl}$ \\
\hline \multicolumn{7}{|l|}{ Stomach (151) } \\
\hline$<15$ years' employment & 4 & 2.33 & $0.79-5.33$ & - & .. & .. \\
\hline$\geq 15$ years' employment & 2 & 0.77 & $0.13-2.43$ & 21 & 1.55 & $1.04-2.24$ \\
\hline \multicolumn{7}{|l|}{ Gallbladder (156) } \\
\hline$<15$ years' employment & - &.. & .. & - &.. & .. \\
\hline$\geq 15$ years' employment & - &.$\cdot$ & .. & 4 & 2.04 & $0.70-4.67$ \\
\hline \multicolumn{7}{|l|}{ Skin melanoma (172) } \\
\hline$<15$ years' employment & 6 & 3.12 & $1.36-6.15$ & - &.. & .. \\
\hline$\geq 15$ years' employment & 3 & 1.25 & $0.34-3.23$ & 8 & 1.68 & $0.84-3.03$ \\
\hline \multicolumn{7}{|l|}{ Prostate (185) } \\
\hline$<15$ years' employment & 2 & 1.06 & $0.18-3.34$ & - & .. & .. \\
\hline$\geq 15$ years' employment & 16 & 1.68 & $1.05-2.55$ & 82 & 1.44 & $1.19-1.73$ \\
\hline \multicolumn{7}{|l|}{ Bladder (188) } \\
\hline$<15$ years' employment & 2 & 0.85 & $0.15-2.67$ & - & .. & .. \\
\hline$\geq 15$ years' employment & 1 & 0.24 & $0.01-1.12$ & 12 & 0.58 & $0.33-0.94$ \\
\hline \multicolumn{7}{|l|}{ Myeloid leukemia (205) } \\
\hline$<15$ years' employment & 2 & 2.33 & $0.40-7.31$ & - & .. & .. \\
\hline$\geq 15$ years' employment & - & .. & .. & 5 & 1.67 & $0.66-3.52$ \\
\hline \multicolumn{7}{|l|}{ All leukemia (204- 208) } \\
\hline$<15$ years' employment & 3 & 1.81 & $0.49-4.66$ & - & .. & .. \\
\hline$\geq 15$ years' employment & 1 & 0.49 & $0.02-2.30$ & 14 & 1.66 & $1.00-2.59$ \\
\hline
\end{tabular}

a Code of the International Classification of Diseases, ninth revision, in parentheses.

referent and incidence studies $(2-4,7,8,16)$, and associations between stomach cancer and chemicals to which workers in the pulp and paper industry are exposed, particularly calcium oxide fumes, sulfur dioxide and sulfuric acid mists, have been described $(24,25)$. Dietary factors, particularly the consumption of smoked, cured and salted food, and cigarette smoking (26), which have been associated with an increased risk of stomach cancer, cannot be excluded, since information on lifestyle factors was not available in our study. However, the fact that stomach cancer was observed among the workers exposed to both the kraft and sulfite processes and not among those exposed only to the kraft or to the sulfite process separately only suggests a role for combined occupational exposures. The association with rectal cancer among the long-term workers in the sulfite process was difficult to interpret. Such a relationship has been reported in a mortality study (4), but in none of the incidence studies (15-17). The excess risk for pleural cancer probably represents past asbestos exposure (1, 23 ), since all except 1 of the 10 cases were mesotheliomas. The leukemia risk observed in our study, which has been previously reported in the pulp and paper industry $(4-6,16)$, was not related to any specific leukemia subtype.

Scand J Work Environ Health 2001, vol 27, no 2 
To our knowledge, this cancer-incidence cohort study specifically carried out in the pulp and paper industry is the first to report an increased risk for prostate cancer and skin melanoma. With respect to prostate cancer, data from previous mortality studies $(11,12)$ and from a recent case-referent study of 1516 incident prostate cancer cases (27) have shown similar relationships. Several chemicals to which pulp and paper workers may be exposed have been associated with a risk of prostate cancer, including cellulose and formaldehyde (24). Risk factors for skin melanoma are mainly related to skin constitution, intermittent sun exposure, and the propensity to sunburn (28); controlling for these factors was not possible in our study. Evidence for occupational risk factors in the pulp and paper industry was not documented for skin melanoma in a large case-referent study with exposure assessment (29), nor reported in cancer incidence studies carried out in this industry (15-17). The incidence rates of both prostate cancer and skin melanoma in British Columbia are significantly increased when compared with Canadian rates (21); thereby the possibility of an overestimated risk in our study is raised. We therefore reanalyzed our data using British Columbia cancer incidence rates. The relative risks for skin melanoma became reduced to nonsignificant levels, whereas that for prostate cancer remained significantly elevated for the long-term workers exposed to both the kraft and sulfite processes, but not for the total cohort (data not shown). The decreased risks for developing cancer of the colon, bladder, and lung cancer observed in this cohort when compared with the national rates may be due to the fact that the British Columbia rates for these cancers are lower than the national ones (21).

Differences were observed between the results of the mortality and incidence cohorts. In particular, the significantly increased risks from cancer of the esophagus (workers employed in both the kraft and sulfite processes), kidney (all workers and workers employed in the kraft process only), and brain (all workers) and from Hodgkin's disease (workers employed in the sulfite process only) among the long-term workers in the mortality cohort (1) were not confirmed in this incidence study. An in-depth look at the 2 sets of data, cancer mortality and incidence, identified likely reasons for most of the discrepancies noted. It must first be pointed out that, in Canada, national statistics are available from 1950 onwards for mortality and from 1969 onwards for cancer incidence and that differences in the mortality rates across Canada for the cancer sites referred to are negligible (30). For Hodgkin's disease, a subanalysis of the mortality data showed that the increased risk was confined to the period 1950-1968, all three deaths among the long-term workers occurring during that time. Thus the cancer incidence results for the period
1969 - 1992, showing no excess risk, concur with the mortality findings for the same time period.

Discrepancies between the pathological diagnosis of cancer and cause of death as listed on death certificates for cancers of the esophagus, kidney, and brain range between $7 \%$ to $14 \%$ (31) and may be considerably higher (32). We reviewed the pathological diagnosis of all the long-term workers who died from these 3 types of tumors between 1969 and 1992 in British Columbia and compared the diagnoses listed on the death certificates with those on the pathology reports obtained from the British Columbia Cancer Registry. There were 16 cases of death listed as esophageal cancer; of these, 6 cases $(38 \%)$ were adenocarcinomas of the stomach on the pathology report. Thus the statistically significant results for cancer of the esophagus noted in the mortality study were correctly attributed to stomach cancer according to more precise topography and morphology data. Similarly, 4 of 18 cases (22\%) of kidney cancer and 3 of 19 cases (16\%) of brain cancer were attributed to other tumor sites on the pathology reports. Correcting the causes of death for these 3 cancer sites resulted in nonsignificantly elevated SMR values for the 19691992 period.

In conclusion, the results of this cancer incidence study, in addition to documenting a risk of mesothelioma likely due to past asbestos exposure, point to a significant excess risk among long-term workers in the pulp and paper industry for (i) prostate and stomach cancers and all leukemias among workers employed in both the kraft and sulfite processes and (ii) cancer of the rectum among workers employed in the sulfite process only. This study also indicates that precise diagnosis and the characteristics of mortality and cancer incidence databases need to be taken into consideration if the results of occupational or environmental studies investigating cancer risks are to be interpreted accurately.

We are currently completing mill-specific and period-specific job exposure matrices (33) that will be used in a nested case-referent study with detailed exposure assessment by job titles. That study should help to evaluate whether the differences in chemical exposures among a subset of workers may further explain the excess risk for specific cancers identified in our mortality and cancer incidence studies.

\section{Acknowledgments}

This research was supported by grants from the Forest Industry Health Research Program and the Worker's Compensation Board of British Columbia.

The authors gratefully acknowledge the invaluable collaboration of research assistants Donna Kan, Joanne Moody and Bill Threlfall. The authors are indebted to 
Emily Fowler and Heather Neidig for their secretarial support. The authors also extend special thanks to Dr Martha Fair, Chief, Occupational and Environmental Health Research, Statistics Canada, for performing the record linkage.

\section{References}

1. Band PR, Le ND, Fang R, Threlfall WJ, Astrakianakis G, Anderson JTL, et al. Cohort mortality study of pulp and paper mill workers in British Columbia, Canada. Am J Epidemiol 1997;146:186-194.

2. Milham S Jr, Demers RY. Mortality among pulp and paper workers. J Occup Med 1984;26:844-46.

3. Robinson CF, Waxweiler RJ, Fowler DP. Mortality among production workers in pulp and paper mills. Scand Work Environ Health 1986;12:552-60.

4. Schwartz E. A proportionate mortality ratio analysis of pulp and paper mill workers in New Hampshire. Br J Ind Med 1988;45:234-38.

5. Henneberger PK, Ferris BG Jr, Monson RR. Mortality among pulp and paper workers in Berlin, New Hampshire. Br J Ind Med 1989; 46:658-64.

6. Solet D, Zoloth SR, Sullivan C, Jewett J, Michaels DM. Patterns of mortality in pulp and paper workers. J Occup Med 1989; 31:627-30.

7. Wingren G, Persson B, Thorén K, Axelson O. Mortality pattern among pulp and paper mill workers in Sweden: a case-referent study. Am J Ind Med 1991; 20:769-74.

8. Torén K, Sällsten G, Järvholm B. Mortality from asthma, chronic obstructive pulmonary disease, respiratory system cancer and stomach cancer among paper mill workers: a case-referent study. Am J Ind Med 1991;19:729—37.

9. Sala-Serra M, Sunyer J, Kogevinas M, McFarlane D, Antó JM. Cohort study on cancer mortality among workers in the pulp and paper industry in Catalonia, Spain. Am J Ind Med 1996;30:87-92.

10. Wong O, Ragland DR, Marcero DH. An epidemiologic study of employees at 7 pulp and paper mills. Int Arch Occup Environ Health 1996;68:498-507.

11. Szadkowska-Stanczyk I, Boffetta P, Wilczynska U, Szeszenia-Dabrowska N, Szymczak W. Cancer mortality among pulp and paper workers in Poland. Int J Occup Med Environ Health 1997;10:19-29.

12. Gallagher RP, Threlfall WJ. Cancer risk in wood and pulp workers. In: Stich HF, editor. Carcinogens and mutagens in the environment; vol V. Boca Raton (FL): CRC Press, 1995: $125-37$.

13. Matanoski GM, Kanchanaraksa S, Lees PSJ, Tao X-U, Royall R, Francis $M$ et al. Industry-wide study of mortality of pulp and paper mill workers. Am J Ind Med 1998;33:354365.

14. Wild P, Bergeret A, Moulin JJ, Lahmar A, Hours M. Mortality in the French paper and pulp industry. Rev Epidemiol Santé Publique 1998;46:85-92.

15. Jäppinen $P$, Hakulinen $T$, Pukkala E, Tola S, Kurppa K. Cancer incidence of workers in the Finnish pulp and paper industry. Scand J Work Environ Health 1987;13:197-202.
16. Rix BA, Villadsen E, Lynge E. Cancer Incidence of sulfite pulp workers in Denmark. Scand J Work Environ Health 1997;23:458-61.

17. Langseth $\mathrm{H}$, Andersen A. Cancer incidence among women in the Norwegian pulp and paper industry. Am J Ind Med 1999;36:108-13.

18. Breslow NE, Day NE. Statistical methods in cancer research; vol II (the design and analysis of cohort studies). Lyon: International Agency for Research on Cancer (IARC), 1987. IARC scientific publication no 82 .

19. Felligi IP, Sunter AB. A theory of record linkage. J Am Stat Assoc 1969;40:1183-210.

20. Howe GR, Lindsay J. A generalized iterative record linkage computer system for use in medical follow-up studies. Comput Biomed Res, 1981;14:327—40.

21. Band PR, Gaudette LA, Hill BC, Holowaty EJ, Huchcroft SA, Jonhston GM, et al. The making of the Canadian Cancer Registry: cancer incidence in Canada and its regions, 1969 to 1988. Ottawa (Canada): Canadian Council of Cancer Registries, Health and Welfare Canada and Statistics Canada, 1993.

22. World Health Organization (WHO). International classification of diseases. Manual of the international statistical classification of diseases, injuries, and causes of death. 9th revision. Geneva (Switzerland): WHO, 1977.

23. Järvholm B, Malker H, Malker B, Ericsson J, Sällsten G. Pleural mesotheliomas and asbestos exposure in the pulp and paper industries: a new risk group identified by linkage of official registries. Am J Ind Med 1988;13:561—7.

24. Siemiatycki J. Risk factors for cancer in the workplace. Boca Raton (FL): CRC press, 1991.

25. Cocco P, Ward MH, Dosemeci M. Ocupational risk factors of the gastric cardia: analysis of death certificates from 24 US states. J Occup Environ Med 1998;40:855-61.

26. Neugut AI, Hayek M, Howe G. Epidemiology of gastric cancer. Semin Oncol 1996;23:281-91.

27. Band PR, Le ND, Fang R, Threlfall WJ, Gallagher R. Identification of occupational cancer risks in British Columbia ( $\mathrm{Pt}$ 11): a population-based case-control study of 1516 prostatic cancer cases. J Occup Environ Med 1999;41:233-47.

28. Elwood JM, Jopson J. Melanoma and sun exposure: an overview of published results. Int J Cancer 1997;73:198—203.

29. Fritschi L, Siemiatycki J. Melanoma and occupation: results of a case-control study. Occup Environ Med 1996;53:16873 .

30. National Cancer Institute of Canada: Canadian Cancer Statistics 1990. Toronto (Canada): National Cancer Institute of Canada, 1990.

31. Gobbato F, Vecchiet F, Barbierato D, Melato M, Manconi R. Inaccuracy of death certificate diagnoses in malignancy: an analysis of 1,405 autopsied cases. Hum Pathol 1982;13: 1036-8.

32. Percy C, Stanek E III, Gloeckler L. Accuracy of cancer death certificates and its effect on cancer mortality statistics. Am J Public Health 1981;71:242-50.

33. Astrakianakis G, Anderson JTL, Band PR, Keefe AR, Bert JL, Le $\mathrm{N}$ et al. Job-exposure matrices and retrospective exposure assessment in the pulp and paper industry. Appl Occup Environ Hyg 1998;13:663-70.

Received for publication: 12 July 2000 